\title{
KONTRIBUSI SYAIKH MUHAMMAD THAHIR JALALUDDIN DALAM BIDANG ILMU FALAK
}

\author{
Arwin Juli Rakhmadi Butar-Butar \\ Fakultas Agama Islam Universitas Muhammadiyah Sumatera Utara \\ J1. Kapten Mucthar Basri No.3, Glugur Darat II, Medan, Sumatera Utara, 20238 \\ e-mail: arwinjuli@umsu.ac.id
}

\begin{abstract}
Abstrak: Fajar adalah fenomena alami yang terjadi disebabkan rotasi Bumi pada porosnya. Permasalahan awal waktu fajar senantiasa menjadi kajian baik di kalangan fukaha maupun ilmuwan Muslim. Di Indonesia, sejak lama berlaku ketetapan dip20 derajat di bawah ufuk dalam penentuan waktu Subuh. Ketentuan ini berasal dari pendapat Syaikh Muhammad Thahir Jalaluddin (w. 1376/1956) dalam karyanya Nukhbah al-Taqrîrât fi Hisâb al-Auqât. Makalah ini akan menelusuri pemikiran Syaikh Muhammad Thahir Jalaluddin tentang hal ini melalui karyanya tersebut dalam merumuskan konsepsi 20 derajat ini. Melalui analisis dan penelusuran sejumlah literatur, ditemukan bahwa dip -20 derajat ini ternyata dihasilkan hanya berdasarkan nukilan dari karya dan atau pemikiran tokoh-tokoh sebelumnya baik tokoh Nusantara maupun tokoh yang bermukim di Haramain, khususnya melalui kitab al-Mathla al-Sa îd karya Husain Zaid Mesir.
\end{abstract}

\begin{abstract}
Shaykh Muhammad Thahir Jalaluddin's Contribution in Islamic Astronomy. This article studies on the early dawn time and its influence on the determination dawn in Indonesia. Dawn is a natural phenomenon that can be seen while the earth rotates on its axis. The issue of the beginning of dawn has become a heated debate both within the Indonesian Muslim scholars (fuqaha) and scientists alike. In Indonesia, to determine dawn prayer's time has been set up dip -20 degree below the horizon. This determination was adopted from Muhammad Thahir Jalaluddin's

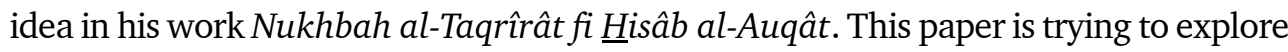
Muhammad Thahir Jalaluddin's thought concerning the issue through his work which formulated this conception of 20 degree. In this article, the author found that after a thorough and critical analysis of some important literature and references, it is concluded that this conception was strictly quoted from other works and other previous Muslim scholars idea who lived in Haramain, especially in the book al-

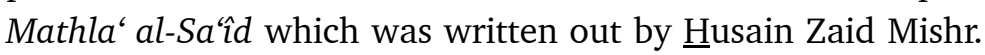

Kata Kunci: Muhammad Thahir Jalaluddin, waktu fajar, Nusantara, astronomi 


\section{Pendahuluan}

Persoalan awal waktu fajar (Subuh) di Indonesia belakangan ini ramai di perbincangkan. Penelitian ISRN UHAMKA menghasilkan dip-13.4 derajat untuk waktu Subuh. ${ }^{1}$ Sebelum itu, diskursus waktu Subuh di Indonesia juga telah mengemuka melalui Majalah Qiblati (tahun 2009) yang terbit sampai tiga edisi, yang juga mengonfirmasi bahwa standar awal waktu Subuh di bawah 20 derajat.

Fajar adalah fenomena alam yang bersifat harian akibat rotasi bumi pada porosnya. Di kalangan fukaha, permasalahan ini menjadi pembahasan yang tak luput dibicarakan. Para fukaha sepakat bahwa awal waktu Subuh adalah ketika terbit fajar. Sementara itu di kalangan ilmuwan Muslim, kajian mengenai fajar (dan senja) juga sudah sejak lama dikaji dan dipelajari. Demikian lagi di Indonesia, kajian mengenai awal waktu fajar (guna menetapkan awal waktu Subuh) juga dilakukan oleh ulama-ulama Nusantara dahulu. Salah satu ulama Nusantara yang mengkaji masalah ini adalah Syaikh Muhammad Thahir

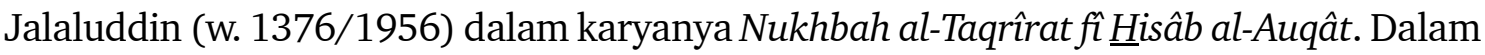
karyanya ini Syaikh Muhammad Thahir Jalaluddin menetapkan standar waktu Subuh adalah 20 derajat di bawah ufuk timur. Standar ini juga adalah yang digunakan sampai hari ini di Indonesia dan beberapa negara Asia Tenggara. Oleh karena itu, adalah penting ditelusuri sejauh mana akurasi standar dip -20 ini yang ditetapkan Syaikh Muhammad Thahir Jalaluddin, baik dari sisi syariat maupun dari sisi sains.

Konsekuensi dari perbedaan standar awal fajar ini adalah rentang perbedaan yang cukup jauh. Sebab, dalam setiap 1 derajat sama dengan durasi 4 menit. Jika merujuk hasil penelitian ISRN UHAMKA di atas yang menetapkan 13,4 derajat, maka akan terdapat perbedaan sekitar 26 menit lebih lama dengan standar awal waktu Subuh 20 derajat sebagai berlaku hari ini. Tentu hal ini merupakan problem di Indonesia yang harus dicarikan penyelesaiannya.

Oleh karena itu, telaah terhadap pemikiran Syaikh Muhammad Thahir Jalaluddin tentang awal waktu fajar ini menjadi penting. Apa yang dikemukakan Syaikh Muhammad Thahir Jalaluddin sejatinya juga menyuguhkan fakta historis kepada pengkaji dan pemerhati Ilmu Falak di Indonesia dan Asia Tenggara. Kenyataannya beberapa literatur Ilmu Falak klasik di Indonesia hingga saat ini masih berpedoman pada pendapat Sa'adoe'din Djambek yang notabenenya berguru kepada Syaikh Muhammad Thahir Jalaluddin. Oleh karena itu dengan melakukan analisis terhadap karya dan pemikiran Syaikh Muhammad Thahir Jalaluddin ini akan memberi gambaran dan analisis historis tentang anggitan ketinggian $-20^{\circ}$ untuk waktu Subuh, dengan demikian pula akan ditemukan validasinya.

Dari uraian di atas, dapat dirumuskan beberapa hal berikut: (1) apa argumentasi Syaikh Muhammad Thahir Jalaluddin dalam menetapkan awal waktu Subuh 20 derajat.

${ }^{1}$ Tono Saksono, Evaluasi Awal Waktu Subuh \& Isya (Perspektif Sains, Teknologi, dan Syariah) (Jakarta: UHAMKA Press, t.t.), h. viii. 
(2) apa konsekuensi adanya perbedaan standar kedalaman fajar dalam penentuan awal waktu Subuh tersebut.

\section{Metode Penelitian}

Tulisan ini mengkaji pemikiran Syaikh Muhammad Thahir Jalaluddin (w. 1376/1956) dan pengaruhnya dalam penetapan waktu Subuh di Indonesia. Di sini akan dikemukakan biografi intelektual Syaikh Muhammad Thahir Jalaluddin untuk melihat latar sosialintelektual serta faktor-faktor lain yang memengaruhi pemikirannya dalam bidang ilmu falak, khususnya dalam masalah standardisasi waktu Subuh. Kajian tentang ini penting untuk dibahas mengingat tiga hal. Pertama, urgensi waktu Subuh itu sendiri. Seperti dimaklumi, sebagaimana disebutkan dalam ayat-ayat dan hadis-hadis terkait bahwa waktu-waktu salat (khususnya waktu Subuh) kerap terkait dengan satu fenomena langit bernama fajar sadik. Fenomena fajar sendiri berbeda antara satu tempat dengan tempat lain, dan berbeda pula dari satu periode waktu dengan periode waktu lainnya, sehingga hal ini penting untuk dikaji secara terus menerus.

Kedua, diskursus tentang awal waktu Subuh belakangan ini banyak mengemuka bahkan menjadi diskursus di kalangan umat Islam khususnya di Indonesia, yang mana hal ini sangat terkait dengan sah tidaknya ibadah salat. Oleh karena itu hal ini memiliki urgensi untuk dikaji. Ketiga, posisi dan keberadaan Syaikh Muhammad Thahir Jalaluddin yang secara tidak langsung ikut melahirkan konsep ketinggian 20 derajat di bawah ufuk sebagai digunakan hari ini. Hal yang patut digali lebih jauh adalah bahwa standar 20 derajat ini terhitung paling tinggi jika dibandingkan dengan standar di negara-negara lain, khususnya di kawasan Timur Tengah. Selanjutnya metode kajian dalam penelitian ini adalah analisis isi dan pemikiran, di mana sumber utamanya adalah pemikiran Syaikh Muhammad Thahir Jalaluddin dalam beberapa karyanya dan pengaruhnya dalam penetapan waktu Subuh di Indonesia.

\section{Hasil dan Pembahasan}

\section{Terminologi Fajar}

Secara bahasa, fajar (al-fajr) adalah pencahayaan gelap malam dari sinar pagi. Para ulama sepakat bahwa fajar ada dua yaitu fajar kazib dan fajar sadik. Fajar kazib (al-fajr al-kâdzib) disebut juga dengan fajar pertama (al-fajr al-awwâl) karena muncul pertama kali dan berikutnya disusul munculnya fajar sadik. Tanda-tanda alami fajar kazib adalah ia muncul menjulang ke langit laksana seekor serigala dan sesaat kemudian menghilang. ${ }^{2}$

2Ibn Manzhur, Lisân al-Áâab, cet. 4 (Beirut: Dâr Shâdir, 2005), h. 130-131. Sirhân dapat bermakna Serigala atau Singa. Fajar kazib di sini dimaknai menyerupai ekor Serigala yang berwarna 
Sementara itu fajar sadik (al-fajr al-shâdiq) disebut juga fajar kedua (al-fajr al-tsâny). Dinamakan demikian oleh karena ia muncul setelah fajar kazib. Tanda-tanda alami fajar sadik adalah tampak menyebar di sepenjuru ufuk dengan warna keputih-putihan. ${ }^{3}$ Cahayanya terus bertambah sampai akhirnya terbit matahari. Menurut Wahbah al-Zuhaili, fajar sadik yang menjadi pertanda dimulainya awal Subuh adalah cahaya putih yang nampak dan menyebar di ufuk timur yang muncul beberapa saat setelah fajar kazib. Dua fajar ini muncul secara bergantian, sehingga munculnya fajar kazib menjadi syarat bagi munculnya fajar sadik. $^{4}$

Menurut al-Nawawi (w. 676 H/1277 M), dinamakan fajar kazib (dusta) adalah karena fajar ini pada awalnya tampak (muncul) dan bersinar namun kemudian menghilang. Sementara itu dinamakan fajar sadik karena ia dikategorikan benar-benar tampak dan jelas, dan ia menjadi pertanda tiba dan dimulainya waktu Subuh. ${ }^{5}$ Di dalam al-Qur'an, istilah fajar disebut dengan dua istilah yaitu al-khaith al-abyadh (benang putih) sebagai fajar sadik dan al-khaith al-aswad (benang hitam) sebagai fajar kazib. Dua istilah ini ditemukan dalam Q.S. al-Baqarah/02: 187, "Dan makan minumlah hingga terang bagimu benang putih dari benang hitam, yaitu fajar" (Q.S. al-Baqarah/02: 187). Benang putih (al-khaith al-abyadh) dalam ayat ini dipahami sebagai batas dimulainya puasa yang mana ia muncul setelah munculnya benang hitam (al-khaith al-aswad). Sementara itu, melalui interpretasi ulama, dipahami bahwa silih bergantinya siang dan malam ditandai dengan tiga warna senja yaitu warna merah, warna putih, dan gelap. ${ }^{6}$

\section{Biografi Syaikh Thahir Jalaluddin}

Nama lengkap Syaikh Thahir Jalaluddin adalah Muhammad Thahir bin Muhammad bin Jalaluddin Ahmad bin Abdullah. Ia berasal dari Minangkabau dan lebih dikenal dengan Syaikh Thahir Jalaluddin. Dia lahir di Cangking, Sumatera Barat, tahun 1286 H/ 1869 M, dan meninggal dunia di Kuala Kangsar, Perak, tahun 1376 H/1956 M. Ia berasal dari keluarga ulama dan taat beragama. Ayahnya adalah tokoh di Minangkabau dengan gelar Syaikh Cangking, yang juga anak seorang ulama bernama Ahmad Jalaluddin (dengan gelar Tuanku Sami).

Thahir Jalaluddin memiliki 5 orang bersaudara, namun sejak kanak-kanak dia telah

hitam, hanya saja bagian dalam ekornya berwarna putih. Fajar kazib sendiri berwarna putih bercampur warna hitam.

${ }^{3}$ Ibid. h. 509.

${ }^{4}$ Wahbah al-Zuhaili, al-Fiqh al-Islâmî wa Adillatuhu, Juz 1, cet. 3 (Beirut: Dâr al-Fikr, 1989),

${ }^{5}$ Muhyyiddîn bin Syarf al-Nawawî, Kitâb al-Majmû' Syarh al-Muhadzdzab li al-Syîrâzi, Juz 3 (Jeddah: Maktabah al-Irsyâd, t.t.), h. 46.

"Imâm Qusthâlani, "Kajian Fajar dan Syafaq Perspektif Fikih dan Astronomi," dalam Mahkamah: Jurnal Kajian Hukum Islam, Vol 3, No. 1, Juni 2018, h. 3. 
ditinggal kedua orang tuanya. Ayahnya meninggal tatkala usianya 2 tahun, sedangkan ibunya meninggal tatkala 9 tahun. Thahir Jalaluddin diasuh oleh Limbak Urai, ibu dari Syaikh Ahmad Khatib Minangkabau (w. 1334 H/1916 M). ${ }^{7}$

Tatkala berusia 11 tahun, Thahir Jalaluddin pergi ke Mekah untuk menuntut ilmu. Di Mekah dia tinggal bersama Syaikh Ahmad Khatib di rumah Syaikh Muhammad Shalih al-Kurdi (mertua Ahmad Khatib). Syaikh Muhammad Shalih al-Kurdi adalah seorang pedagang buku terkemuka yang memiliki kedekatan dengan raja (Syarif) Husain. Segenap kebutuhan Thahir Jalaluddin waktu itu dipenuhi oleh Syaikh Ahmad Khatib, yang waktu itu berusia 19 tahun. $^{8}$

Di awal kedatangannya ke Mekah, Syaikh Thahir Jalaluddin belajar ilmu-ilmu tajwid kepada Syaikh 'Abd al- $\underline{H}$ aq. Kemudian dia belajar agama kepada Sayyid 'Umar Syathâ, Syaikh Muhammad al-Khayyâth (w. 1333 H/1919 M) ${ }^{9}$, dan Sayyid Bakri Syathâ'. Setelah itu, dia mempelajari berbagai bidang ilmu seperti nahu, saraf, ma'ani, badi', mantik, fikih, hadis, tafsir, geometri, dan ilmu falak (astronomi). ${ }^{10}$ Oleh karena itu pula dia memiliki sejumlah karya di bidang ini. Di zamannya, Syaikh Thahir Jalaluddin dikenal sebagai tokoh ilmu falak berpengaruh, sebagaimana halnya Syaikh Ahmad Khatib, Syaikh Ahmad Rifa'i, dan Syaikh Sholeh Darat. Sebelum Syaikh Thahir Jalaluddin, sejatinya telah ada sejumlah ulama yang menguasai ilmu falak seperti Muhammad Nur bin Nik Mat Kecik (Fathani), Jamil Jambek (Minangkabau), Abdullah Fahim (Pulau Pinang), dan Abu Bakar bin Hasan (Johor). ${ }^{11}$

Syaikh Thahir Jalaluddin juga pernah belajar di Mesir (al-Azhar) sekitar tahun 1893 M. Di institusi ini dia belajar selama lebih kurang 3 tahun. ${ }^{12}$ Selama di Mesir, dia banyak dipengaruhi oleh karya dan pemikiran Syaikh Muhammad Abduh.

Salah satu pemikiran Syaikh Thahir Jalaluddin di Nusantara yang cukup kontroversial adalah dukungannya terhadap hisab dalam penentuan awal bulan. Padahal, pandangan populer kala itu (terutama di Sumatera Barat) adalah menggunakan rukyat yang merupakan pendapat para ulama terdahulu. Namun Syaikh Thahir Jalaluddin tetap berpegang teguh

${ }^{7}$ Hamka, Ayahku, Cet. 4 (Jakarta: Umminda, 1982), h. 272.

${ }^{8}$ Mafri Amir, Reformasi Islam Dunia Melayu-Indonesia: Studi Pemikiran, Gerakan, dan Pengaruh Syaikh Muhammad Thahir Jalaluddin 1869-1956 (Jakarta: Badan Litbang dan Diklat Departemen Agama RI, 2008), h. 44-45; Haji Bachtiar Djamily, Riwayat Hidup dan Perjuangan Syeikh Tahir Jalaluddin al-Falaki al-Azhari (Kuala Lumpur: Asmah Publisher, 1994), h. 13-16.

${ }^{9}$ Dia adalah Syaikh Muhammad bin Yusuf al-Khaiyâth (w. 1333 H/1919 M), seorang ulama Mekah yang mengajar berbagai ilmu di al-Masjid al-Haram, khususnya ilmu hisab dan ilmu falak. Lihat Muhammad Thahir Jalaluddin, Pati Kiraan pada Menentukan Waktu yang Lima dan Hala Kiblat dengan Logaritma (Singapura: al-Ahmadiyah Press, 1357/1938), h. 13.

${ }^{10}$ Mafri Amir, Reformasi Islam, h. 45.

${ }^{11}$ Wan Mohd Shaghir Abdullah, Ensiklopedia Naskah Klasik Nusantara (Kuala Lumpur: Khazanah Fathaniyah, 2015), h. 46.

${ }^{12}$ Hamka, Ayahku, h. 275. 
terhadap keyakinannya sembari terus memperdalam pengetahuannya dalam bidang ilmu falak (astronomi).

Di Nusantara, Syaikh Thahir Jalaluddin tercatat pernah mengembara ke beberapa wilayah seperti Riau (tahun 1892 M), Singapura (tahun 1888 M) dan Malaysia (tahun 1899 M). Di Riau, dia bertemu Raja Muhammad Thahir Hakim, seorang Hakim dari Kesultanan Riau. Dia disarankan untuk tinggal di pulau Penyengat dan mempelajari kitab falak berjudul al-Thal' al-Sa'îd. Syaikh Thahir Jalaluddin juga pernah sampai ke Surabaya, Buleleng, Ampenan (Bali), Pulau Sumbawa, Bima, dan Gowa. Tak pelak, perjalanan dan pengembaraannya ini menegaskan wawasan, peran dan kiprah Syaikh Thahir Jalaluddin di kepulauan Melayu-Nusantara.

Adapun karya-karyanya Syaikh Thahir Jalaluddin dalam bidang ilmu falak adalah:

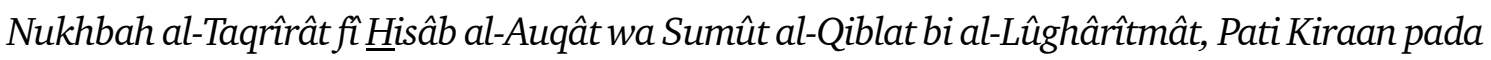
Menentukan Waktu yang Lima dan Hala Kiblat dengan Logaritma, Natîjah al-'Umr, Al-Qiblah fíal-Nushus Ulamâ' al-Syâfi'iyyah fi ma Yata'allaqu bi Istiqbâl al-Qiblah al-Syar'iyyah Manqûlah min Ummahât Kutub al-Madzhab. Di negeri jiran Malaysia, pengaruh Syaikh Thahir Jalaluddin dalam pengembangan ilmu falak sangat besar. Di Pulau Pinang (Malaysia) terdapat sebuah lembaga bernama "Pusat Falak Syeikh Thahir", yang mana lembaga ini dibangun untuk mengenang jasa-jasa beliau.

\section{Karya-Karya Falak Syaikh Thahir Jalaluddin}

Pertama, al-Qiblah fî al-Nushûs Ulamâ’ al-Syâfi'iyah fîmâ Yata'allaq bi Istiqbâl alQiblah al-Syar'iyah Manqûlah min Ummahât Kutub al-Madzhab (Kiblat dalam Teks-Teks Ulama Syafi'iyah Berkaitan Menghadap Kiblat Syar’i Diambil dari Buku-Buku Induk Mazhab) ini adalah karya Syaikh Muhammad Thahir Jalaluddin. Buku ini ditulis dalam dua bahasa, Arab dan Melayu. Sejauh ini tidak ada informasi tentang kapan buku ini ditulis. Buku ini dicetak oleh Percetakan al-Zainiyah (Mathba'ah al-Zainiyah), Taiping, tahun 1951 M. Secara umum, buku ini membicarakan tentang bagaimana menentukan arah kiblat. Seperti dikemukakan Wan Daud, buku ini mendapat apresiasi dari banyak ulama di Malaysia. ${ }^{13}$

Kedua, Jadawil Pati Kiraan Pada Menyatakan Waktu Yang Lima dan Hala Qibalt Dengan Logharitma. Buku ini selesai ditulis pada tanggal 15 Sya'ban 1356 H/1936 M. Cetakan pertama diterbitkan oleh Al-Ahmadiyah Press, Singapura, tahun 1357 H/1938 M. Buku ini dicetak dalam bentuk kombinasi tulisan Melayu-Jawi dan Latin-Rumi. Secara umum, buku ini mengkaji tentang perhitungan-perhitungan astronomis. Pada halaman 13 terdapat catatan tentang guru Syaikh Thahir Jalaluddin, yaitu Syaikh Muhammad bin Yusuf al-Khayyath (Syaikh al-Khayyath). Sang guru ini adalah salah satu ulama Haramain (Mekah), yang mengajar berbagai ilmu (agama) di Masjidil Haram, khususnya ilmu hisab (aritmetika)

\footnotetext{
${ }^{13}$ Wan Mohd. Shaghir Abdullah, Ensiklopedia Naskah Klasik, h. 48.
} 
dan ilmu falak (astronomi). Selain itu, beliau juga pernah ditetapkan menjadi Syaikh Kedah. Syaikh al-Khayyath meninggal dunia di Batuban, Pulau Pinang, pada malam Rabu, tanggal 17 Rajab $1333 \mathrm{H} / 1914$ M. ${ }^{14}$ Buku ini membahas tentang kaidah-kaidah perhitungan ilmu falak dengan menggunakan logaritma. Di dalamnya terdapat sejumlah tabel astronomi dalam bentuk lampiran, di antaranya tabel bujur Matahari, perata waktu, tabel setengah lingkaran matahari, tabel waktu Zuhur, dan contoh-contoh perhitungan waktu salat dan arah kiblat, serta koordinat geografi untuk 136 lokasi di berbagai wilayah (dunia). Pada bagian pendahuluan dijelaskan mengenai penggunaan logaritma dan uraian beberapa istilah yang lazim digunakan dalam perhitungan ilmu falak. Syaikh Thahir juga memperkenalkan unsur-unsur yang biasa digunakan dalam perhitungan ilmu falak yaitu tata cara perhitungan sudut jam Matahari (fadhl al-dẩir) dan zenit Matahari (samt al-syams) dengan menggunakan nilai ketinggian Matahari yang telah diketahui. Bagian akhir "Pati Kiraan" menjelaskan hal yang berkaitan dengan penentuan mihrab dan penggunaan kompas serta teodolit. Judul lengkap buku ini adalah Natîjah al-'Umr Pendapatan Kira-Kira Pada Taqwîm Târîkh Hijry dan Mîlady Hala Qiblah dan Waktu Sembahyang Yang Boleh Digunakan Selama Hidup. Menurut Wan Mohd Shaghir Abdullah, buku ini selesai ditulis tahun 1355 H/1936 M, dicetak oleh Penang Printer Press, Pulau Pinang, tahun 1355 H/1936 M. ${ }^{15}$ Secara umum, buku ini menjelaskan tentang bagaimana mengetahui penanggalan (kalender) Hijriah dan Miladiah, menentukan arah kiblat, dan menentukan waktu-waktu salat untuk selamanya (jadwal abadi). Pada sub judul "Pendahuluan pada menyatakan kandungan natijah ini", disebutkan beberapa pembahasan, yaitu: penanggalan hijriah, penanggalan miladiah, dan konversi antar keduanya. Berikutnya lintang dan bujur suatu daerah, kadar perjalanan matahari, arah kiblat (hala kiblat), dan waktu-waktu salat di suatu daerah. ${ }^{16}$

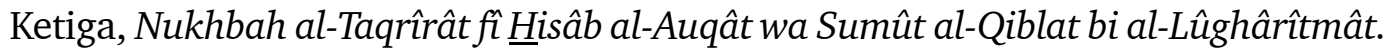
Tidak ada informasi kapan buku ini ditulis. Cetakan pertama buku ini diterbitkan oleh Royal Press, 745 North Bird Road, Singapura, tahun 1356 H/1937 M. Secara umum buku ini membicarakan tentang kaidah-kaidah ilmu falak. Ditulis dalam bahasa Arab, sedangkan tabeltabelnya menggunakan angka-angka Latin. Menurut Wan Mohd Shaghir Abdullah, salah satu naskah buku ini berasal dari Tuan Guru Haji Abu Bakar bin Haji Hasan, seorang Qadhi Muar, Johor. Beliau memerolehnya sebagai hadiah dari penulisnya (Syaikh Thahir Jalaluddin). Dalam naskah itu tertulis "hadiyah wa tazkir li hadhrat al-fadhil Tuan Haji Abu Bakar ibnu Hasan, bekas qadhi Muar, min al-Mu'allif al-haqir Muhammad Thahir Jalaluddin" (hadiah dan kenangan untuk yang terhormat Tuan Haji Abu Bakar bin Hasan, bekas kadi Muar, dari pengarang yang fakir Muhammad Thahir Jalaluddin). ${ }^{17}$

\footnotetext{
${ }^{14}$ Ibid., h. 46.

${ }^{15}$ Ibid.

${ }^{16}$ Muhammad Thahir Jalaluddin, Natîjah al-'Umr (t.t.p.: t.p., 1355 H/1936 M), h. 2-3.

${ }^{17}$ Wan Mohd Shaghir Abdullah, Ensiklopedia Naskah Klasik, h. 47.
} 


\section{Waktu Subuh Menurut Fikih Islam}

\section{Awal Waktu Subuh}

Ulama sepakat bahwa awal waktu Subuh adalah terbitnya cahaya fajar kedua (fajar sadik). ${ }^{18}$ Diperkuat lagi dengan sabda Nabi Saw yang menyatakan seseorang yang salat Subuh ketika sudah mendapatkan satu rakaat sebelum terbit matahari maka ia terhitung sudah mengerjakan salat Subuh. ${ }^{19}$ Warna (cahaya) yang dianggap sebagai pertanda terbitnya fajar sadik adalah cahaya putih, bukan cahaya merah yang datang sesudahnya. Ini berdasarkan hadis riwayat Samurah bin Jundub. ${ }^{20}$ Namun dalam riwayat lain, Nabi SAW. besabda: “... fa kulû wasyrabû hattâ ya'taridha lakum al-ahmar" (makan dan minumlah kalian hingga muncul cahaya merah). Yang dimaksud dengan al-ahmar dalam hadis ini adalah alabyâdh sesuai dengan hadis Samurah. Sebagaimana juga kesepakatan kaum muslimin yang menjadikan standar waktu Subuh adalah terbitnya fajar sadik berupa cahaya putih. Hal ini juga berdasarkan firman Allah “... dan makan minumlah hingga terang bagimu benang putih dari benang hitam, yaitu fajar ...” (Q.S. al-Baqarah/2: 187).

\section{Akhir Waktu Subuh}

Akhir waktu subuh adalah ketika terbit matahari, antara lain berdasarkan hadis riwayat Abu Mûsâ al-Asy'ari, ${ }^{21}$ 'Abdullâh bin 'Amr bin 'Ash, ${ }^{22}$ dan Sulaimân bin Buraidah. ${ }^{23}$ Satu pendapat mengatakan bahwa akhir Subuh adalah ketika al-isfâr (matahari bersinar). ${ }^{24}$ Berdasarkan hadis-hadis ini ulama berbeda pendapat tentang akhir salat Subuh dalam dua pendapat. Pendapat pertama menyatakan bahwa akhir waktu Subuh adalah ketika didapati sekurang-kurangnya satu rakaat sebelum matahri terbit. ${ }^{25}$ Pendapat kedua menyatakan akhir waktu Subuh hingga matahari bersinar (al-isfâr). Pendapat ini didukung oleh Malik, Hanabilah, dan sebagian Syâfiiyah. ${ }^{26}$ Pendapat ini mendasarkan pada hadis imâmah Jibril,

${ }^{18}$ Ibrâhim bin Alî al-Syîrazî, al-Muhadzdzab fỉ Fiqh al-Imâm al-Syâfi'î, Catatan \& Komentar: Zakaria 'Umairat (Beirut: Dâr al-Kutub al-'Ilmiyyah, 1416/1995), h. 103. Muhyiddîn bin Syarf alNawawî, Minhâj al-Thâlibîn wa 'Umdah al-Muftîn (Semarang: Maktabah wa Mathba'ah Toha Putra, t.t.)

${ }^{19}$ Ibn Qudâmah, Al-Mughnî, ditahqîq 'Abdullah bin 'Abd al-Muhsin al-Turki \& 'Abd alFattâh Muhammad al-Halw, cet. 3 (Riyâdh: Dâr 'Âlam al-Kutub, 1417/1997), h. 30.

${ }^{20} \mathrm{HR}$. Muslim, hadis nomor [1094], bab "Bayân anna al-Dukhûl fî al-Shaum Yahshulu bi Thulû' al-Fajr".

${ }^{21}$ Muhyiddîn bin Syarf al-Nawawî, Kitâb al-Majmû' Syarh al-Muhadzdzab, ditahqîiq Muhammad Najîb al-Muthî̀i (Jeddah: Maktabah al-Irsyâd, t.t.), h. 47.

${ }^{22}$ HR. Muslim, hadis nomor [612], bab: "Auqât al-Shalawât al-Khams".

${ }^{23} \mathrm{HR}$. Muslim, hadis nomor [613], bab: "Auqât al-Shalawât al-Khams".

${ }^{24}$ Ibnu Rusyd al-Hifaîdz, Bidâyah al-Mujtahid wa Nihâyah al-Muqtashid (Indonesia: Dâr Ihyâ' al-Kutub al-Arabiyah, t.t.), h. 69.

${ }^{25} \mathrm{HR}$. Muslim, hadits nomor [608], bab "Auqât al-Shalawât al-Khams".

${ }^{26}$ Muhyiddîn bin Syarf al-Nawawî, Kitâb al-Majmû', h. 46. 
dimana kalimat "wa al-waqt fìmâ baina hâdzaini al-waqtain" (diantara dua waktu ini ada dua waktu) menunjukkan bahwa sesudah isfâr bukan waktu Subuh lagi. Konsekuensinya jika seorang Muslim melaksanakan salat dengan melambatkannya hingga sesudah isfâr, maka ia terhitung berdosa. Menurut al-Ishthakhrî (dari kalangan Syafiìah) terhitung sebagai tunda (qadhâ'), ${ }^{27}$ dan menurutnya waktu Subuh berakhir ketika isfâr, waktu sesudahnya terhitung tunda, dan berdosa bagi yang melambatkannya. ${ }^{28}$

\section{Periode Waktu Subuh}

Waktu Subuh ada empat periode waktu: (1) waktu utama (waqt al-fadhîlah) yaitu awal waktu, (2) waktu pilihan (waqt al-ikhtiyâr) yaitu hingga matahari bersinar (isfâr), (3) waktu relatif (waqt al-jawâz) yaitu hingga terbit awan merah matahari, berdasarkan hadis riwayat Muslim yang menyatakan waktu salat Subuh dari sejak terbit fajar sampai sebelum matahari terbit. ${ }^{29}$ (4) waktu terlarang (waqt al-karâhah) yaitu ketika terbit awan merah (al-humrah).

\section{Variabel Astronomis Waktu Salat}

\section{Lintang dan Bujur}

Lintang (Arab: khath al-'aradh) adalah jarak sudut sepanjang titik di atas permukaan bumi dari titik utara maupun titik selatan katulistiwa. Garis lintang pada dasarnya adalah lingkaran semu-paralel terhadap lingkaran bumi yang semakin kecil tatkala mendekati kutub utara dan kutub selatan. ${ }^{30}$ Nilai suatu lintang tempat adalah $0^{\circ}$ sampai $90^{\circ}$. Lintang bagi tempat-tempat yang berada di belahan bumi utara disebut Lintang Utara (LU) diberi tanda positif $(+)$, dan tempat-tempat yang berada di belahan bumi selatan disebut Lintang Selatan (LS) diberi tanda negatif $(-)$.

Bujur (Arab: khath al-thûl) adalah jarak sudut suatu tempat (wilayah) di permukaan bumi yang diproyeksikan sepanjang ekuator bumi dihitung dari meridian yang melewati kota Greenwich (sesuai kesepakatan internasional tahun 1884). Bujur suatu tempat juga dapat diasumsikan sebagai lingkaran besar-semu yang melalui dua kutub (utara-selatan) yang melalui katulistiwa. Nilai bujur suatu tempat berkisar antara $0^{\circ}$ sampai $180^{\circ}$. Bagi tempat-tempat yang berada di sebelah barat Greenwich disebut Bujur Barat (BB) dan diberi tanda negatif (-), sedangkan bagi tempat-tempat yang berada di sebelah timur Greenwich disebut Bujur Timur (BT) dan diberi tanda positif $(+)$.

${ }^{27}$ Ibid.

${ }^{28}$ Ibid.

${ }^{29} \mathrm{HR}$. Muslim, kitab: al-Masâjid, bab "Auqât al-shalawât al-khams [1388].

30‘Abd al-Amir Mu'min, Qâmûs Dâr al-'Ilm al-Falaky (Beirut: Dâr al-'Ilm li al-Malâyîn, 2006), h. 187. 
Mengetahui lintang dan bujur suatu tempat merupakan dasar perhitungan arah kiblat, waktu salat, awal bulan, dan gerhana. Arti penting lintang dan bujur dalam penentuan waktu salat adalah terkait dengan posisi suatu tempat yang akan dihitung waktu-waktu salatnya. Perbedaan posisi geografis suatu wilayah sejatinya akan memberi perbedaan waktuwaktu salat.

\section{Bujur (Waktu) Tolok}

Bujur (Waktu) Tolok adalah perbedaan waktu antara satu tempat dengan tempat yang lain karena adanya perbedaan bujur tempat. Berdasarkan KEPRES No. 41 tahun 1987 Negara Republik Indonesia dibagi menjadi tiga wilayah waktu. Pertama, Waktu Indonesia Barat (WIB) dengan bujur tolok $105^{\circ}$ BT atau GMT + 7 jam. Waktu Indonesia Barat meliputi: Sumatera, Jawa, Madura, Kalimantan Barat, Kalimantan Tengah. Kedua, Waktu Indonesia Tengah (WITA) dengan bujur tolok $120^{\circ}$ BT atau GMT +8 jam. Waktu Indonesia Tengah meliputi: Kalimantan Timur, Kalimantan Selatan, Bali, Nusa Tenggara Barat, Nusa Tenggara Timur, Timor-Timur, Sulawesi. Ketiga, Waktu Indonesia Timur (WIT) dengan bujur tolok $135^{\circ}$ BT atau GMT + 9 jam. Waktu Indonesia Timur meliputi: Maluku dan Irian Jaya. ${ }^{31}$

Bujur (Waktu) Tolok ini dapat disebut juga dengan zona waktu lokal. Pemahaman terhadap variabel bujur waktu ini adalah guna menjelaskan di posisi waktu mana kita sedang berada. Zona waktu nol berarti posisi di kota Greenwich, London, Inggris. Zona Barat dari kota itu bernilai negatif, sebaliknya, sebelah Timur, bernilai positif. Sebagi contoh, kota Medan memiliki zona waktu $\mathrm{z}=+7$ jam (atau ditulis secara singkat GMT +7 ).

\section{Ketinggian}

Variabel ketinggian suatu lokasi dari atas permukaan laut merupakan hal penting dalam penentuan waktu-waktu salat. Ketinggian lokasi (dalam satuan meter) dari permukaan laut sangat menentukan kapan matahari terbit dan terbenam.

Jika kita menggunakan referensi koordinat topografik, maka sistem koordinat bumi dinyatakan dalam tiga dimensi (x, y, z), dimana z adalah faktor ketinggian tempat. Acuan ini memperlakukan permukaan bumi sesuai topografinya. Pada ketinggian tertentu di suatu lokasi sejatinya akan memberi pengaruh dalam konteks penentuan ketinggian matahari sebagai pedoman penentuan waktu-waktu salat. Secara empirik, ketika hendak menyaksikan obyek yang berada dalam posisi di horizon jauh, obyek itu masih terlihat pada ketinggian tertentu. Namun pada ketinggian 0 meter obyek itu tidak dapat terlihat lagi. Ini menunjukkan

${ }^{31}$ Lihat Keputusan Presiden Republik Indonesia Nomor 41 tahun 1987 tentang Pembagian Wilayah Republik Indonesia dalam Ephemiris Hisab Rukyat 2010 (Direktorat Urusan Agama Islam dan Pembinaan Syariah Ditjen Bimbingan Masyarakat Islam, Departemen Agama), h. 390-392. 
bahwa faktor ketinggian cukup berpengaruh terhadap kenampakan suatu obyek. ${ }^{32}$ Oleh karena itu pula, lokasi yang berada lebih tinggi dari atas permukaan laut tentunya akan lebih dahulu menyaksikan matahari terbit. Sebaliknya, lokasi yang berada lebih rendah dari atas permukaan laut akan lebih terlambat menyaksikan matahari terbenam.

\section{Kerendahan Ufuk}

Kerendahan ufuk adalah perbedaan kedudukan antara ufuk yang tampak secara zahir dengan ufuk yang terlihat bagi seorang pengamat dari atas permukaan laut. ${ }^{33}$ Untuk mencari kerendahan ufuk biasanya digunakan rumus dip $=1.76$ “m/60. Koreksi kerendahan ufuk diperlukan untuk menunjukkan bahwa ufuk yang terlihat bukan ufuk yang berjarak 90 dari titik zenit, melainkan ufuk mar'i yang jaraknya dari titik zenit tidak tetap, artinya tergantung pada tinggi rendahnya si peninjau. ${ }^{34}$ Misal, kita akan menentukan kerendahan ufuk dari suatu tempat dengan ketinggian 30 meter dari atas permukaan laut. Maka perhitungannya, dip $=1.76$ “30/60 $=0^{\circ}$ 9' 38.4”.

Dalam bahasa Inggris, kerendahan ufuk disebut "dip" dan dalam bahasa Arab disebut "inhithâth al-ufuq" atau "ikhtilâfal-ufuq".

\section{Semi Diameter}

Semi Diameter adalah jarak titik pusat matahari dengan piringan luarnya, atau seperdua garis tengah piringan matahari (jari-jari). Data ini diperlukan dalam penentuan waktu salat guna menghitung secara tepat saat matahari terbit dan terbenam. Semi Diameter (SD) dalam bahasa Arab disebut nishfal-quthr dan dalam istilah bahasa Indonesia dikenal dengan jari jari matahari.

\section{Refraksi}

Refraksi (Arab: daqâ’iq al-ikhtilâf) adalah pembiasan sinar matahari. Refraksi menyatakan selisih antara ketinggian benda langit menurut penglihatan dengan ketinggian sebenarnya. ${ }^{35}$ Semakin rendah kedudukan sebuah benda langit maka semakin besar pula refraksinya. Refraksi diperlukan untuk menghitung ketinggian matahari pada saat terbit dan pada saat terbenam. Koreksi refraksi juga diperlukan untuk memperoleh informasi tentang posisi matahari yang sesungguhnya.

\footnotetext{
${ }^{32}$ Lihat dalam http://aliboron.wordpress.com/2010/10/29/koreksi-ketinggian-tempatwaktu-shubuh-dan-magrib/ (akses: 14 Januari 2014).

${ }^{33} \mathrm{Abd}$ al-Amir Mu'min, Qâmûs Dâr al-'Ilm, h. 69.

${ }^{34}$ Akh. Mukarram, Ilmu Falak Dasar-Dasar Hisab Praktis (Sidoarjo: Grafika Media, 2012), h. 58 .

${ }^{35}$ Susiknan Azhari, Ensiklopedi Hisab Rukyat, cet. 2 (Yogyakarta: Pustaka Pelajar, 2008), h.180.
} 
Dalam astronomi dikenal istilah "pembiasan cahaya" akibat suhu dan atau kepadatan udara yang berbeda-beda. Semakin dekat dengan bumi maka udara akan semakin padat. Sebaliknya, semakin jauh, maka akan semakin kurang padat. Akibatnya terjadilah pembelokan cahaya dari benda langit ketika sampai di mata kita.

Refraksi juga dapat diilustrasikan dengan sebuah benda lurus yang dimasukkan kedalam sebuah gelas yang berisi air, maka akan terlihat benda di dalam air itu tidak lurus alias bengkok, dan ujung benda itu terlihat terangkat dari posisinya dan terlihat lebih pendek. Ini menunjukkan bahwa berkas cahaya yang datang dari benda di dalam air sewaktu berpindah dari air ke udara arahnya membelok dari arah semula, sehingga ujung benda itu terlihat lebih tinggi. Inilah yang dinamakan refraksi.

\section{Deklinasi}

Deklinasi Matahari adalah jarak sudut benda langit dari lingkaran ekuator yang diukur sepanjang lingkaran waktu pada kutub utara maupun kutub selatan. ${ }^{36}$ Peristiwa deklinasi menggambarkan pergerakan benda-benda langit baik ke utara maupun ke selatan sesuai kemiringan ekuatornya. Deklinasi bernilai positif $(+)$ apabila matahari berada di sebelah utara ekuator. Sebaliknya, bernilai negatif (-) apabila matahari berada di sebelah selatan ekuator.

Selain dalam penentuan waktu-waktu salat, data deklinasi juga diperlukan dalam penentuan bayang-bayang kiblat, waktu ijtimak, ketinggian hilal, gerhana, dan lain-lain. Dengan mengetahui deklinasi matahari, maka posisi matahari terhadap bumi akan dapat ditentukan. Deklinasi matahari dalam bahasa Inggris disebut "Apparent Declination of the Sun", dan dalam bahasa Arab disebut "mail al-syams".

Nilai deklinasi matahari setiap hari selalu berubah, namun dalam setiap tahunnya relatif sama. Mulai tanggal 21 Maret samapi 23 September, deklinasi bernilai positif. Sedangkan mulai tanggal 23 September sampai 21 Maret, deklinasi bernilai negatif. Sejak tanggal 21 Maret, matahari berkedudukan di ekuator, dengan demikian deklinasinya nol derajat. Memasuki tanggal 21 Juni, yaitu ketika matahari bergerak ke utara dan menjauhi ekuator, deklinasinya senilai $23^{\circ} 27^{\prime}$ utara. Tanggal 23 September, matahari bergerak ke selatan dan berkedudukan di ekuator kembali. Tanggal 22 Desember, matahari mencapai posisi terjauh dari ekuator yaitu $23^{\circ} 37^{\prime}$ Selatan. Pada akhirnya matahari bergerak balik ke utara dan mendekati ekuator, dan pada tanggal 21 Maret matahari kembali tepat di ekuator.

Dari penjelasan di atas, tampak bahwa deklinasi matahari senantiasa berubah. Perubahan itu tidak hanya dari hari ke hari, namun dari jam ke jam. Perubahan deklinasi paling besar adalah tatkala matahari berkedudukan di ekuator yaitu sekitar tanggal 21 Maret dan 23

${ }^{36} \mathrm{~A}$. Weigert \& H. Zimmerman, al-Mausû'ah al-Falakiyyah, terj. Abdul Qawi 'Iyâd (Kairo: Maktabah al-Usrah, Mahrajân al-Qirâ'ah li al-Jamî' 2002), h. 521. 
MIQOT Vol. XLII No. 2 Juli-Desember 2018

September, dan perubahan paling kecil tatkala matahari dalam gerak tahunan baliknya, yaitu sekitar tanggal 21 Juni dan 22 Desember. ${ }^{37}$

\section{Perata Waktu}

Perata waktu adalah selisih antara waktu kulminasi matahari hakiki dengan waktu kulminasi matahari pertengahan. ${ }^{38}$ Perata waktu biasanya dinyatakan dengan huruf e dan dalam bahasa Arab disebut mu'âdalah al-waqt atau mu'âdalah al-zaman, atau terkadang disebut juga ta'dîl al-waqt. Dalam bahasa Inggris disebut equation of time.

Analisis hukum Kepler memberi informasi bahwa gerak edar matahari tidak tetap. Matahari dalam mencapai titik kulminasi tidak selalu tepat pada jam 12:00, namun terkadang kurang dari jam 12:00, terkadang lagi lebih dari jam 12:00. Oleh karena itu para ahli astronomi merumuskan apa yang dinamakan dengan matahari pertengahan yang mengasumsikan matahari selalu mencapai titik kulminasinya tepat jam 12:00.

Antara waktu hakiki dan waktu pertengahan ini dapat diilustrasikan sebagai berikut: ketika matahari hakiki berada di meridian, matahari pertengahan masih berada di sebelah timurnya. Dalam keadaan ini, ketika matahari hakiki berada pada pukul 12:00, namun sesungguhnya menurut waktu matahari pertengahan belum mencapai pukul 12:00, misalnya masih pukul 11:54. Oleh karena itu besarnya perata waktu pada waktu itu adalah 12:00$11: 54=+6$ menit.

Sebaliknya, ketika matahari pertengahan 'terdahulu' (berada di sebelah barat meridian) dari matahari hakiki. Maka ketika waktu hakiki berada pada pukul 12:00, waktu pertengahan sudah menunjukkan pukul 12:00 lebih, kita misalkan pukul 12:06. Oleh karena itu besarnya perata waktu pada saat itu adalah $12: 00-12: 06=-6$ menit.

Bila diperhatikan, nilai perata waktu ini adakalanya positif dan adakalanya negatif. Nilai perata waktu (e) bernilai positif adalah apabila MP (Merr Pass) kurang dari 12, dan negatif apabila lebih besar dari 12. Dan karena selisih waktu hakiki dan waktu pertengahan ini selalu tidak sama-disebabkan tempuhan bumi yang selalu tidak sama-, maka angka perata waktu setiap harinya juga selalu berubah, meskipun dari satu tahun ke tahun relatif sama. Grafik tahunan perata waktu yang tampak tidak sama. Seperti telah dikemukakan, ketidaksamaan grafik ini disebabkan tempuhan bumi yang berbentuk elips serta adanya kemiringan ekliptika, yang mana seluruhnya melakukan pengaruhnya masing-masing. Selisih antara waktu matahari hakiki (yang tidak teratur) dengan matahari pertengahan (yang teratur) inilah yang dinamakan dengan perata waktu.

${ }^{37}$ M. Sayuthi Ali, Ilmu Falak I (Jakarta: RajaGrafindo Persada, 1997), h. 12.

${ }^{38}$ Mohamad Ahmad Sulaiman, al-Qâmûs al-Muyassar fi 'Ilm al-Falak wa al-Fadhâ' (Helwan: al-Ma'had al-Qaumy li al-Buhûts al-Falakiyyah wa al-Jiyûfizîqiyyah, t.t.), h. 58. 


\section{Ihtiyâth}

Ihtiyâth secara bahasa adalah tindakan pencegahan dan pengamanan dengan mengambil sesuatu yang meyakinkan dan meneguhkan. Sementara itu menurut syarak, ihtiyat adalah menjaga diri (jiwa) dari terjatuh pada sesuatu yang terlarang (baik bersifat haram maupun makruh) yaitu dengan menjauhi sesuatu yang meragukan dan meninggalkan beberapa yang boleh. ${ }^{39}$

Dalam konteks penentuan waktu salat, ihtiyâth yang dimaksud disini adalah kehatihatian sebagai suatu langkah pengamanan dengan cara menambah dan atau mengurangi hasil perhitungan yang berkisar antara 1 menit sampai 3 menit atau lebih. Menurut Susiknan Azhari, ihtiyâth antara lain bertujuan: (1) agar hasil perhitungan dapat mencakup daerah-daerah sekitarnya, (2) menjadikan pembulatan hasil hitungan pada satuan terkecil dalam menit waktu, sehingga penggunaannya lebih mudah (3) untuk memberikan koreksi atas reduksi dalam perhitungan agar menambah keyakinan bahwa waktu salat benar-benar dilaksanakan dalam waktunya.

Landasan dalil ihtiyâth ini antara lain berdasarkan hadis yang diriwayatkan oleh al-Nu'mân bin Basyir:

Dari al-Nu'mân bin Basyir-semoga Allah meridai keduanya-, ia berkata, "Aku mendengar Rasulullah Saw bersabda: "Sesungguhnya yang halal itu jelas dan yang haram itu jelas, dan diantara keduanya ada perkara yang samar-samar, kebanyakan manusia tidak mengetahuinya, maka siapa menjaga dirinya dari yang samar-samar itu, berarti ia telah menyelamatkan agama dan kehormatannya, dan siapa yang terjerumus dalam wilayah samar-samar maka ia telah terjerumus ke dalam wilayah yang haram, seperti penggembala yang menggembala di sekitar daerah terlarang maka hampir-hampir dia terjerumus kedalamnya. Ingatlah, setiap raja memiliki larangan, dan ingatlah bahwa larangan Allah apa-apa yang diharamkan-Nya. Ingatlah, bahwa dalam jasad ada segumpal daging jika ia baik maka baiklah seluruh jasadnya dan jika ia rusak maka rusaklah seluruh jasadnya. Ketahuilah, bahwa segumpal daging itu adalah hati (HR. Muslim). ${ }^{40}$

Dari hadis ini dapat ditarik benang merah ihtiyâth, bahwa Nabi Saw. menginformasikan ihtiyat dengan meninggalkan sesuatu yang syubhat ada maslahat yaitu membebaskan (istabra'a) agama dan kehormatan, dan ini sesuatu yang terpuji menurut syariat. Kemudian Nabi Saw. juga menginformasikan bahwa terjerumus pada syubhat di dalamnya ada kerusakan, yaitu terjatuh pada sesuatu yang haram, adakalanya secara langsung maupun tunda, dan ini tercela menurut syariat. ${ }^{41}$ Landasan ihtiyâth juga berdsarkan hadis riwayat

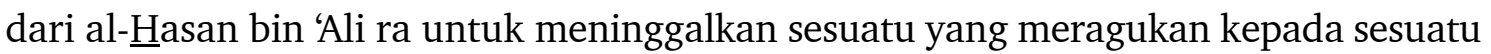

${ }^{39}$ Mustafâ bin Karamatullâh Makhdûm, Qawâ'id al-Wasâill fỉ asy-Syarîah al-Islâmiyyah (Riyâd: Dâr Isybîliyâ, 1420/1999), h. 494-495.

${ }^{40}$ HR. Muslim, bab "al-Masâqah" 3/1219 nomor 1599.

${ }^{41} \mathrm{Jâmi}$ ' al-'Ulûm wa al-Hikam I/205. 
MIQOT Vol. XLII No. 2 Juli-Desember 2018

yang tidak meragukan. ${ }^{42}$ Dimana Nabi SAW. sangat menganjurkan kepada setiap muslim untuk meninggalkan sesuatu yang meragukan -di antaranya sesuatu yang syubhat-, yang mana ini adalah esensi dari ihtiyâth.

\section{Konsep Awal Waktu Fajar Menurut Muhammad Thahir Jalaluddin}

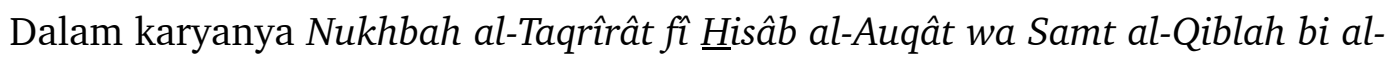
Lughâritmât Syaikh Muhammad Thahir Jalaluddin mengemukakan standar awal waktu Subuh. Menurutnya, standar awal waktu fajar adalah 20 derajat. Thahir Jalaluddin mengatakan, "Dan adapun ketinggian ideal untuk Isya dan Fajar yaitu dengan menambahkan 18 derajat (1) atas 90 untuk Isya, dan 20 derajat untuk Fajar, maka didapatlah ketinggian yang dicari". ${ }^{43}$

Pada kenyataannya, standar 20 ini digunakan oleh Kementerian Agama dan berlaku di seluruh Indonesia. Seperti diketahui, dalam penentuan waktu Subuh, di Indonesia hari ini berlaku ketentuan 20 derajat di bawah ufuk. Ketentuan ini digunakan hampir di seluruh masyarakat Muslim di Indonesia, khususnya Kementerian Agama RI, Nahdlatul Ulama, dan Muhammadiyah. Dalam buku berjudul Pedoman Hisab Muhammadiyah yang diterbitkan Majelis Tarjih dan Tajdid Pimpinan Pusat Muhammadiyah disebutkan bahwa standar waktu Subuh adalah ketika Matahari berada dalam posisi 20 derajat di bawah ufuk. ${ }^{44}$

Sedangkan dalam buku Pedoman Penentuan Jadwal Waktu Shalat Sepanjang Masa yang diterbitkan oleh Departemen Agama RI disebutkan:

Waktu Shubuh dimulai sejak terbit fajar di ufuk timur. H. Saadoeddin Jambek dalam bukunya Shalat dan Puasa di Daerah Kutub dan Drs. Abd. Rachim dalam bukunya "Ilmu Falak" menerangkan bahwa tinggi Matahari saat terbit fajar adalah $-20^{\circ}$. Ada juga ahli-ahli hisab lainnya yang mengatakan bahwa tinggi Matahari awal Shubuh adalah18 atau $18 \frac{1}{2}$ atau -19. Selama ini kita berpedoman h Shubuh -20 seperti apa yang dikemukakan oleh H. Saadoeddin Jambek dan Drs. Abd. Rachim. ${ }^{45}$

Untuk kasus Indonesia, standar 20 derajat ini penting dan menarik untuk ditelusuri, yaitu mengenai kapan standar 20 derajat ini mulai digunakan? Siapa pencetusnya? Apakah standar 20 derajat ini berdasarkan hasil penelitian ataukah nukilan dari sumber-sumber

\footnotetext{
${ }^{42}$ Lihat HR. al-Nasâ'i, bab "al-Asyribah" 8/732 nomor 5727, HR. al-Tirmidzi bab "Abwâb Shifah al-Qiyâmah" 7/205 nomor 2520.

${ }^{43}$ Muhammad Thahir Jalaluddin al-Minkabau, Nukhbah al-Taqrîrât fî Hisâab al-Auqât wa Samt al-Qiblah bi al-Lughâritmât (t.t.p.: t.p., 1356/1937), h. 12.

${ }^{44}$ Lihat: MTT PP Muhammadiyah, Pedoman Hisab Muhammadiyah (Yogyakarta: MTT PP Muhammadiyah, 1430/2009).

${ }^{45}$ Departemen Agama RI, Pedoman Penentuan Jadwal Waktu Shalat Sepanjang Masa (Jakarta: Direktorat Jendral Pembinaan Kelembagaan Agama Islam \& Direktorat Pembinaan Badan Peradilan Agama Islam tahun 1994/1995), h. 32.
} 
tertulis? Apa pula argumentasi ilmiah dan syar'i penggunaan 20 derajat tersebut? Beberapa pertanyaan ini patut diajukan dan penting untuk dijawab. Seperti dimaklumi, standar umum yang berkembang di zaman astronom Muslim dan ulama Nusantara adalah antara 1719 derajat, bukan 20 derajat.

Sejauh informasi yang penulis dapat, standar 20 derajat itu bersumber dari gagasan Saadoe'ddin Jambek dan Abd. Rachim. Selanjutnya melalui penelusuran sejumlah literatur Ilmu Falak Nusantara, diketahui bahwa standar Subuh 20 derajat ini tertera di antaranya

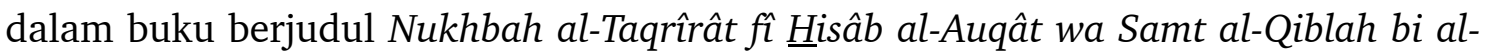
Lûghâritmât yang ditulis oleh Muhammad Thahir Jalaluddin (w. 1376 H/1956 M).

Saadoe'ddin Djambek, tokoh yang dianggap sebagai yang mempopulerkan standar 20 derajat di Indonesia. ${ }^{46}$ Beliau lahir di Bukittinggi pada tanggal 24 Maret $1911 \mathrm{M}(1330 \mathrm{H})$, dan wafat di Jakarta pada tanggal 22 Nopember 1977 M (11 Zulhijah 1397 H). Saadoe'ddin Djambek adalah putra ulama besar Minangkabau bernama Muhammad Djamil Djambek (w. 1367 H/1947 M). Dia tercatat pernah mengemban amanah menjadi salah satu dari lima anggota tim perumus Lembaga Hisab dan Rukyat Departemen Agama. Pada tanggal 16 Agustus 1972 M melalui SK Menteri Agama nomor 76 tahun 1972 M tentang Badan Hisab dan Rukyat Departemen Agama, ia diberi amanah menjadi ketua Badan Hisab dan Rukyat. ${ }^{47}$ Saadoe'ddin Djambek sendiri tercatat pernah berguru kepada Syaikh Thahir Jalaluddin, sosok yang banyak memengaruhi pemikiran dan wawasan ilmu falaknya, ${ }^{48}$ sehingga patut diduga standar 20 derajat itu di populerkan Saadoe'ddin Djambek yang bersumber dari Syaikh Thahir Jalaluddin.

Menjadi pertanyaan lagi adalah, bagaimana Thahir Jalaluddin dan atau Saadoe'ddin Jambek menetapkan standar 20 derajat ini. Bila ditelaah, standar 20 derajat ini agaknya berasal dari buku-buku Ilmu Falak (astronomi) yang pernah dibaca dan dipelajarai Thahir Jalaluddin baik ketika di Haramain maupun ketika di Nusantara khususnya buku al-Mathla al-Saî̀, Taqrîb al-Maqshad karya Husain Zaid Mesir (w. 1887 M). Buku ini dalam beberapa waktu menjadi rujukan utama tokoh-tokoh (ulama) falak Nusantara dalam mengkaji dan mendalami persoalan Ilmu Falak, khususnya memasuki periode pertengahan abad ke-20 M yang merupakan fase pembaruan Ilmu Falak di Nusantara. Karya-karya falak

${ }^{46}$ Hendri, "Fenomena Fajar Shadiq Penanda Awal Waktu Shalat Subuh, Terbit Matahari, dan Awal Waktu Dhuha," dalam al-Hurriyah: Jurnal Hukum Islam, Vol. 02/No. 02, Juli-Desember 2017, h. 158.

${ }^{47}$ Departemen Agama RI, Almanak Hisab Rukyat (Jakarta: Badan Peradilan Agama Islam, t.t.), h. 25.

${ }^{48}$ Saadoe'ddin Djambek memiliki banyak karya tulis yang mayoritasnya di bidang ilmu falak, antara lain: Waktu dan Djadwal Penjelasan Populer Mengenai Perjalanan Bumi, Bulan dan Matahari (Tintamas, 1952 M/1372 H); Almanak Djamiliyah (Tintamas, 1953 M/1373 H); Perbandingan Tarich (Tintamas, 1968 M/1388 H); Pedoman Waktu Sholat Sepanjang Masa (Bulan Bintang, 1974 M/1394 H); Sholat dan Puasa di Daerah Kutub (Bulan Bintang, 1974 M/1394 H); Hisab Awal Bulan Qamariyah (Tintamas, 1976 M/1397 H). Lihat Arwin Juli Rakhmadi Butar-Butar, Mengenal KaryaKarya Ilmu Falak Nusantara (Yogyakarta: LKiS, 2017), h. 44-45. 
sebagai ditulis oleh ulama Nusantara pada periode ini umumnya merupakan repetisi, adaptasi, dan modifikasi dari al-Mathla' al-Saî̀d, selain buku-buku lainnya. ${ }^{49}$ Dalam al-Mathla' alSa îd sendiri tertera bahwa standar waktu fajar adalah 19 derajat. Tercatat, Ahmad Khatib Minangkabau (w. 1334 H/1915 M) menulis buku berjudul al-Qaul al-Mufid Syarh Mathla al-Sa îd yang merupakan syarah dari al-Mathla' al-Sa îd. Demikian lagi Muhammad Jamil Djambek juga menulis ringkasan terhadap al-Mathla' al-Sa'îd ini.

Selain al-Mathla' al-Saî̀d, tercatat ada beberapa buku lagi yang berkembang dan dipelajari ulama Nusantara waktu itu baik di Haramain maupun Nusantara antara lain Tsamarât al-Wasîlah Liman Arâda al-Fadhîlah karya Khalifah bin Hamad al-Nabhany dan Mukhtashar fì Ma'rifah al-Sinîn wa al-Rub'al-Musytahir karya Ahmad Zaini Dahlân (w. 1304 H/1886 M). Dua karya ini juga menetapkan standar waktu fajar 19 derajat.

Lantas, mengapa yang berkembang dan digunakan hari ini 20 derajat, bukan 19 derajat? Sejauh ini penulis tidak dan atau belum mendapat kejelasan tentangnya. Namun patut diduga bahwa peralihan dari 19 derajat ke 20 derajat itu adalah penggenapan semata atau dalam rangka kehati-hatian. Di kalangan astronom Muslim sendiri tradisi menggenapkan dalam rangka kehati-hatian ini ada dan dipraktikkan. Antara lain Ibn al-Mufty (Abu Zaid 'Abd al-Rahmân bin 'Umar al-Susy al-Bu'aqily) [w. 1003 H/1594 M] dalam salah satu pernyata-annya pernah mempraktikkan kehati-hatian standar syafak (Isya) dari 17 derajat menjadi 18 derajat. ${ }^{50}$

Patut dicatat, sejumlah ulama Nusantara yang betapapun sebagian mereka adalah ahli falak, namun tidak ditemukan informasi bahwa mereka memiliki zij atau tradisi observasi simultan, demikian lagi dalam uraian karya-karya mereka tidak ada indikasi demikian. Standar angka sebagai tertera dalam karya-karya mereka tampaknya hanya nukilan dari buku-buku lain yang mereka baca.

\section{Penutup}

Dalam karyanya Nukhbah al-Taqrîrât fî Hisấb al-Auqât wa Samt al-Qiblah bi alLûghâritmât, Syaikh Muhammad Thahir Jalaluddin menetapkan standar awal waktu Subuh -20 derajat. Rumusan dip-20 untuk awal waktu fajar (Subuh) sebagai berkembang di Indonesia sejatinya berasal dari pendapat Saadoe'din Jambek, yang notabenenya bersumber dari pemikiran dan pendapat Syaikh Muhammad Thahir Jalaluddin. Sejauh penelusuran literatur yang ada, pemikiran Saadoe'din Jambek dan Syaikh Muhammad Thahir Jalaluddin sesungguhnya dihasilkan berdasarkan nukilan dari karya dan atau pemikiran kitab-kitab sebelumnya yang pernah dikaji dan dipelajari baik di Nusantara maupun di

${ }^{49} \mathrm{Ibid}, \mathrm{h} .2$.

${ }^{50}$ Lihat, Muhammad Syaukat Audah, "Isykâliyyât Falakiyyah wa Fiqhiyyah Haula Tahdîd Mawâqît al-Shalâh," makalah dalam "Mu'tamar al-Imârât al-Falaky ats-Tsâny", Abu Dhabi, 30 Mei-1 Juni 2010, h. 48. 
Haramain, khususnya melalui kitab al-Mathla'al-Sa îd karya Husain Zaid Mesir. Dalam konteks modern, rumusan awal waktu fajar -20 derajat perlu untuk dikaji dan direkonstruksi ulang dengan kajian modern guna memberikan rumusan terakurat tentang anggitan awal waktu Subuh di Indonesia. Dalam segenap uraiannya, Syaikh Muhammad Thahir Jalaluddin tidak memberi penjelasan tentang aspek fisis dan matematis tentang awal waktu fajar tersebut sehingga patut untuk dikaji lebih jauh.

\section{Pustaka Acuan}

Abdullah, Wan Mohd Shaghir. Ensiklopedia Naskah Klasik Nusantara. Kuala Lumpur: Khazanah Fathaniyah, 2015.

Al-Hafîdz, Ibnu Rusyd. Bidâyah al-Mujtahid wa Nihâyah al-Muqtashid. Indonesia: Dâr Ihyâ' al-Kutub al-'Arabiyah, t.t.

Ali, M. Sayuthi. Ilmu Falak I. Jakarta: RajaGrafindo Persada, 1997.

al-Nawawî, Muhyiddîn bin Syarf. Kitâb al-Majmû' Syarh al-Muhadzdzab li al-Syîrâzi, Juz 3. Jeddah: Maktabah al-Irsyâd, t.t.

Al-Nawawî, Muhyiddîn bin Syarf. Kitâb al-Majmû‘ Syarh al-Muhadzdzab, Ditahkik Muhammad Najîb al-Muthî̀i. Jeddah: Maktabah al-Irsyâd, t.t.

Al-Nawawî, Muhyiddîn bin Syarf. Minhâj al-Thâlibîn wa 'Umdah al-Muftîn. Semarang: Maktabah wa Mathba'ah Toha Putra, t.t.

Al-Syîrazî, Ibrâhim bin Alî. al-Muhadzdzab fĩ Fiqh al-Imâm al-Syâfi î, Catatan \& Komentar: Zakariâ' 'Umairat. Beirut: Dâr al-Kutub al-'Ilmiyyah, 1416/1995.

al-Zuhaili, Wahbah. al-Fiqh al-Islâmî wa Adillatuhu, Juz 1, cet. 3. Beirut: Dâr al-Fikr, 1989.

Amir, Mafri. Reformasi Islam Dunia Melayu-Indonesia: Studi Pemikiran, Gerakan, dan Pengaruh Syaikh Muhammad Thahir Jalaluddin 1869-1956. Jakarta: Badan Litbang dan Diklat Departemen Agama RI, 2008.

Audah, Muhammad Syaukat. "Isykâliyyât Falakiyyah wa Fiqhiyyah Haula Tahdîd Mawâqît al-Shalâh," makalah dalam "Mu'tamar al-Imârât al-Falaky ats-Tsâny", Abu Dhabi, 30 Mei-1 Juni 2010.

Azhari, Susiknan. Ensiklopedi Hisab Rukyat, cet. 2. Yogyakarta: Pustaka Pelajar, 2008.

Departemen Agama RI. Almanak Hisab Rukyat. Jakarta: Badan Peradilan Agama Islam, t.t.

Departemen Agama RI. Pedoman Penentuan Jadwal Waktu Shalat Sepanjang Masa. Jakarta: Direktorat Jendral Pembinaan Kelembagaan Agama Islam \& Direktorat Pembinaan Badan Peradilan Agama Islam tahun 1994/1995.

Djamily, Haji Bachtiar. Riwayat Hidup dan Perjuangan Syeikh Tahir Jalaluddin al-Falaki al-Azhari. Kuala Lumpur: Asmah Publisher, 1994.

Hamka. Ayahku, cet. 4. Jakarta: Umminda, 1982. 
MIQOT Vol. XLII No. 2 Juli-Desember 2018

Hendri. "Fenomena Fajar Shadiq Penanda Awal Waktu Shalat Subuh, Terbit Matahari, dan Awal Waktu Dhuha", dalam al-Hurriyah: Jurnal Hukum Islam, Vol. 02/No. 02, Juli-Desember 2017.

Ibn Qudâmah. Al-Mughnî, ditahkik 'Abdullâh bin 'Abd al-Muhsin al-Turki \& 'Abd al-Fattâh Muhammad al-Halw, cet. 3. Riyâdh: Dâr 'Âlam al-Kutub, 1417/1997.

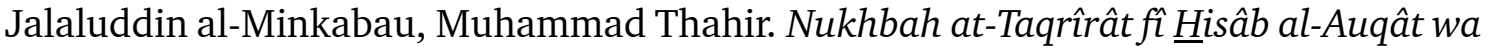
Samt al-Qiblah bi al-Lughâritmât. t.t.p.: t.p., 1356/1937.

Jalaluddin, Muhammad Thahir. Natîjah al-'Umr. t.t.p.: t.p., 1355 H/1936 M.

Jalaluddin, Muhammad Thahir. Pati Kiraan pada Menentukan Waktu yang Lima dan Hala Kiblat dengan Logaritma. Singapura: al-Ahmadiyah Press, 1357/1938.

Makhdûm, Mustafâ bin Karamatullâh. Qawâ’id al-Wasâ’il fî asy-Syarî‘ah al-Islâmiyyah. Riyâd: Dâr Isybîliyâ, 1420/1999.

Manzhur, Ibn. Lisân al-Arab, cet. 4. Beirut: Dâr Shâdir, 2005.

MTT PP Muhammadiyah. Pedoman Hisab Muhammadiyah. Yogyakarta: MTT PP Muhammadiyah, 1430/2009.

Mu'min, 'Abd al-Amir. Qâmûs Dâr al-'Ilm al-Falaky. Beirut: Dâr al-'Ilm li al-Malâyîn, 2006.

Mukarram, Akh. Ilmu Falak Dasar-Dasar Hisab Praktis. Sidoarjo: Grafika Media, 2012.

Qusthâlani, Imâm. "Kajian Fajar dan Syafaq Perspektif Fikih dan Astronomi," dalam Mahkamah: Jurnal Kajian Hukum Islam, Vol 3, No. 1, Juni 2018.

Saksono, Tono. Evaluasi Awal Waktu Subuh \& Isya (Perspektif Sains, Teknologi, dan Syariah). Jakarta: UHAMKA Press, t.t.

Sulaimân, Muhamad Ahmad. al-Qâmûs al-Muyassar fị 'Ilm al-Falak wa al-Fadhâ'. Helwan: al-Ma'had al-Qaumy li al-Buhûts al-Falakiyyah wa al-Jiyûfizîqiyyah, t.t.

Weigert, A. \& H. Zimmerman. al-Mausû'ah al-Falakiyyah, terj. Abdul Qawi 'Iyâd. Kairo: Maktabah al-Usrah, Mahrajân al-Qirâ'ah li al-Jamî’ 2002. 